\title{
Clinico-Microbiological Study of Dengue Virus Infection in a Tertiary Care Hospital
}

\author{
Arjun Gajananrao Jadhav ${ }^{1}$, Anil Arjunrao Gaikwad ${ }^{2 *}$ and Ajit S. Damale ${ }^{3}$ \\ ${ }^{1}$ Department of Microbiology, SRTRGMC Ambajogai, Maharashtra, India \\ ${ }^{2}$ Department of Microbiology, GMC Aurangabad, Maharashtra, India \\ ${ }^{3}$ Department of Microbiology, Indian Institute of Medical Science \& Research Jalna, \\ Maharashtra, India \\ *Corresponding author
}

\section{Keywords}

Laboratories,

Diagnostics,

Prophylactics,

Therapeutics, Borne

viral disease

\section{Article Info}

Accepted:

12 November 2019

Available Online:

10 December 2019

\section{A B S T R A C T}

Dengue fever is an arthropod borne viral disease present as either a non-specific illness, dengue fever (DF) or DHF, DSS leading to hospitalization or death. In routine laboratories diagnosis is mainly based on the detection of dengue antigens (NS1) or antibodies (IgM and IgG) by ELISA kits. Objectives of the study are to find out the seropositivity of dengue virus infection in patients admitted in a tertiary care hospital and to study the clinical presentation of dengue in serologically diagnosed cases. The study was conducted Department of Microbiology, GMC Aurangabad. Samples from Clinically suspected cases of Dengue are collected along with clinical profile and Patients were divided into two groups, Group A containing patients having fever history of 5 days or less than 5 days and Group B containing patients having fever history of more than 5 days. Serum samples from both Group A and Group B were tested by Rapid Immunochromatographic Card test (RICT). In addition to RICT, Serum samples from Group A were subjected to NS1 ELISA and serum samples from Group B subjected to IgM Capture ELISA. Out of 390 clinically suspected dengue cases 138 cases $(35.38 \%)$ were serologically positive by RICT and or ELISA.111 cases were positive by RICT. In Group A (180 samples), 55 samples were positive by NS1 ELISA and In Group B (210 samples), 83 samples were positive by IgM ELISA. A total of 55 cases i.e. $30.55 \%(55 / 180)$ were positive for NS1 ELISA as compared to 42 Cases i.e. $23.34 \%$ (55/180) by RICT for NS1 Ag (During 1-5 days of Fever) in Group A. A total of 83 cases i.e. $39.52 \%$ (83/210) were positive for IgM ELISA as compared to 66 cases i.e. $31.42 \%$ (83/210) by RICT for IgM Ab (During 6-10 days of fever) in Group B. NS1 antigen was detectable in patient's sera from day one of fever, IgM antibodies from day 3 onwards. Out of 138 dengue positive cases, majority of the cases i.e. 84 (60.87\%) were having dengue fever without warning signs, followed by 39 cases $(28.26 \%)$ cases of dengue with warning signs and 15 cases $(10.86 \%)$ had severe dengue. Fever was most common clinical presentation followed by Headache, bodyache, nausea, vomiting, joint pain, abdominal pain, retro-orbital pain and rash, hemorrhagic manifestations. Hepatomegaly was the commonest clinical sign followed by ascites, pleural effusion and Splenomegaly. Death occurred in 4 $(2.89 \%)$ cases. RICT provide the useful aids in screening and ELISA should be considered as the confirmatory test in diagnosis of dengue.NS1 ELISA has promising results in early diagnosis of dengue and when used in combination with IgM Capture ELISA it increases the diagnostic efficiency. Hence involvement of good laboratories for early and prompt diagnosis of dengue infection, coupled with vector control programmes and inducing awareness among the public, is needed in combating future epidemics of dengue. 


\section{Introduction}

Dengue fever is an important arthropod (mosquito) borne viral disease of tropics and subtropics affecting urban and periurban areas. It is a self limiting disease transmitted by bite of an infected female Aedes mosquito (Manohar et al., 2015). According to the World Health Organization (WHO) estimates, the incidence of dengue has increased by a factor of 30 over the last 50 years (Dussart et al., 2006). 2.5 billion people are at risk in 100 tropical and subtropical regions of the world. Fifty million dengue infections occur worldwide annually. It affects up to 100 million people each year with 500,000 cases of dengue hemorrhagic fever (DHF) and dengue shock syndrome (DSS) causing around 30000 deaths (Patil et al., 2014). Dengue is now endemic in more than 100 countries (Dussart et al., 2006).

In several Asian countries, dengue is the leading cause of hospitalization and death in children.

Hence, there is a need for diagnostics, prophylactics and therapeutics to manage it (Shrivastava et al., 2011).

Infection with a dengue virus may be clinically inapparent or may present as a nonspecific febrile illness, classic dengue fever or DHF. Classic dengue fever is characterized by fever, malaise, headache, arthralgia, myalgia and rash. DHF is characterized by onset of plasma leakage, marked thrombocytopenia and bleeding diathesis. Severe plasma leakage can lead to DSS with mortality rate for untreated patients being in excess of $10 \%$ (Vaughn et al., 1998).

Primary DENV infections present as either a non-specific illness or dengue fever (DF). Secondary infection with a serotype different from that causing primary infection may lead to DHF or DSS (Moorthy et al., 2009).
Several approaches have been applied for laboratory diagnosis of dengue virus infections.

These methods include detection of the virus (by cell culture or immunofluorescence), detection of virus antigen (Ag) (by enzymelinked immunosorbent assay [ELISA]), detection of anti-dengue virus antibody (by hemagglutination inhibition [HI], complement fixation test $[\mathrm{CF}]$, neutralization test, or ELISA), and detection of virus nucleic acids (by reverse transcription [RT]-PCR or realtime RT-PCR).(Wang SM et al.,2010). Thus, in a majority of cases the only feasible diagnosis is based on the detection of dengue antigens or antibodies (Shrivastava et al., 2011).

Dengue $\operatorname{IgM}$ and IgG ELISA kits are widely used for diagnosis of dengue infection in routine laboratories. However, there are variations in detection limit during acute phase of the disease (Ahmed et al., 2014). An ELISA specific to dengue virus NS1 protein has been developed for the detection of dengue NS1 antigen during the acute phase of disease in patients experiencing primary and secondary infections (Shrivastava et al., 2011).

The recently introduced dengue rapid kits rapid immunochromatographic card test (RICT) in Indian market are combination packs, which detect circulating NS1 antigen, a highly conserved viral protein and $\operatorname{IgM}$ and IgG (Stephen et al., 2014)

Currently, no effective antiviral agents to treat dengue infection are available. The management of dengue virus infection is essentially supportive and symptomatic. With limited therapeutic strategies and the current lack of a vaccine, A rapid and accurate diagnosis of dengue in the acute phase of illness is important for initiation of therapy \& forecasting an early warning of an epidemic 
and in undertaking effective vector control measures are essential to reduce denguerelated mortality and morbidity (Shrivastava et al., 2014; Mahapatra et al., 2014; Gupta et al., 2014). The present study was to evaluate utility of serodiagnosis of dengue virus infection and to study clinical profile in serologically diagnosed cases. It will help the clinicians in early diagnosis, proper management and effective treatment which may minimize the complications.

To find out the seropositivity of dengue virus infection in patients admitted in a tertiary care hospital.

To study the clinical presentation of dengue in serologically diagnosed cases.

\section{Materials and Methods}

The present study was conducted in a tertiary care hospital in the Department of Microbiology after obtaining approval from the institutional Ethical Committee.

The study was carried out over a period of one $\&$ half years from January 2014 to June 2015 .

\section{Inclusion criteria}

The clinically suspected patients of dengue virus infection admitted in a tertiary care hospital

The clinically suspected patients of dengue virus infection presented within 1-10days of fever

Those ready to give informed written consent

\section{Exclusion criteria}

Patients with history of fever which the clinician doesn't correlate with dengue virus infection were excluded.
Fever with any other proven microbial illness (bacterial, viral, parasitic infection)

The clinically suspected patients of dengue virus infection presented with fever more than 10 days.

Those not ready to give informed written consent.

\section{Type of study}

Prospective, observational, descriptive study

\section{Sample size}

The clinically suspected patients of dengue virus infection admitted in tertiary care hospital during study period from January 2014 to June 2015

\section{Clinical data}

After informed consent, the clinical data of suspected patients was collected as per Performa.

\section{Sample collection}

By using universal aseptic precautions 2-3ml of blood of the patient clinically suspected of dengue fever were collected by the referral departments in plain bulb

\section{Laboratory methods}

Blood in plain bulb sent to microbiology laboratory was centrifuged at $3000 \mathrm{rpm}$ for 5 min and serum was separated.

Patients were divided into two groups,

Group A having fever history of 5 days or less than 5 days.

Group B having fever history of more than 5 days. 
All Serum samples of group A and Group B were tested by rapid immunochromatographic card test (RICT) according to manufacturer's guidelines (dengue NS1 Ag and Ab Combi Card test, J Mitra and Co. Pvt. Ltd., New Delhi India). Then all samples in group A were subjected to NS1 ELISA according to manufacturer's guidelines. (DENGUE NS1 Ag MICROLISA manufactured by J.Mitra \& Co. Pvt. Ltd New Delhi, India)

All samples in group B were subjected to IgM Capture ELISA according to manufacturer's guidelines (manufactured by National Institute of virology Pune, India).

Based on clinical and laboratory findings dengue positive cases were classified into

Dengue without warning signs

Dengue with warning signs

Severe dengue

\section{Results and Discussion}

The present study was carried out in a tertiary care hospital during one $\&$ half year period from January 2014 to June 2015. Patients were divided into two groups, Group A containing 180 patients having fever history of 5 days or less than 5 days and Group B containing 210 patients having fever history of more than 5 days. Serum samples from both Group A and Group B $(180+210=390)$ were tested for the presence of NS1 antigen, IgM and IgG antibodies by Rapid Immunochromatographic Card test (RICT). In addition to RICT, Serum samples from Group A (180 Samples) were subjected to NS1 ELISA and serum samples from Group B (210 samples) subjected to IgM Capture ELISA.

Out of 390 clinically suspected dengue cases 138 cases $(35.38 \%)$ were serologically positive shown in Table 1. In Group A (180 samples), 55 samples were positive by RICT \&/or NS1 ELISA and In Group B (210 samples), 83 samples were positive by RICT \&/or IgM ELISA. Out of 390 clinically suspected dengue cases (Group A and Group B) 138 cases $(35.38 \%)$ were positive shown in Table 2.

In the present study, fever was present in all $138(100 \%)$ of cases. Headache was the second most common clinical presentation which was observed in $107(77.53 \%)$ cases followed by bodyache in $92(66.67 \%)$ cases, nausea and vomiting in $66(47.82 \%)$ cases, joint pain in $63(45.65 \%)$ cases, abdominal pain in $53(38.40 \%)$ cases, retro-orbital pain in $53(38.40 \%)$ cases, rash in $30(21.73 \%)$ cases, hemorrhagic manifestations in 21 (15.21\%) cases shown in Graph 1.

Hepatomegaly was the commonest clinical sign, which was found in 21 cases $(15.21 \%)$ followed by ascites in 16 cases (11.59\%). pleural effusion in $14(10.14 \%)$ and Splenomegaly in 11 cases $(7.97 \%)$ shown in Table 3.

Out of 138 dengue cases death occurred in 4 $(2.89 \%)$ cases.

Majority of the cases i.e. 84 (60.87\%) were having dengue fever without warning signs, followed by 39 cases $(28.26 \%)$ cases of dengue with warning signs and 15 cases $(10.86 \%)$ had severe dengue shown in Table 4. 111 cases were positive by RICT and of which majority cases were only $\operatorname{IgM}$ antibody positive i.e. $48(43.24 \%)$ cases followed by only NS1 antigen positive cases i.e. 27 $(24.32 \%)$ shown in Table 5.

RICT detects either NS1 Ag, IgM or IgG antibodies. Samples positive for only NS1 Ag or only IgM Ab or NS1 Ag and IgM Ab were classified as primary dengue infections. 
Samples positive for IgG Ab, or NS1 Ag and IgG $\mathrm{Ab}$, or IgM and IgG Ab or NS1 Ag, IgM $\mathrm{Ab}$ and $\mathrm{IgG} \mathrm{Ab}$ were classified as secondary dengue infections. Of the 111 positive cases by RICT, 89 cases $(80.18 \%$; 89/111) were classified as primary dengue and remaining 22 $(19.82 \%$; 22/111) cases as secondary dengue infection shown in Table 6.

The results shows NS1 antigen was detectable in patient's sera from day one of fever, IgM antibodies from day 3 onwards and NS1 Ag was detected in patients sera till the $8^{\text {th }}$ day of fever by RICT shown in Table 7.

From the table it is evident that RICT NS1 Ag positivity was seen more in Group A 42(84\%) than in Group B 8(16\%) and RICT IgM Ab positivity was seen more in Group B 66(88\%) than in Group A 9(12\%).

This has been found to be statistically significant $(\mathrm{p}<0.0001)$ as shown in Table 8. A total of 55 cases i.e. $30.55 \%$ were positive for NS1 ELISA as compared to 42 Cases i.e. $23.34 \%$ by RICT for NS1 Ag (During 1-5 days of Fever) in Group A as shown in Table 9.

A total of 83 cases i.e. $39.52 \%$ were positive for IgM ELISA as compared to 66 cases i.e. $31.42 \%$ by RICT for IgM Ab (During 6-10 days of fever) in Group B as shown in Table 10 .

The results table shows NS1 ELISA Positivity for NS1 Ag was $30.55 \%$ and IgM ELISA Positivity for $\operatorname{IgM~Ab}$ was $39.52 \%$ as shown in Table 11.

\section{Seropositivity}

In the present study seropositivity of dengue was $35.38 \%$, which is in accordance with Ukey et al., (31.3\%), Sandhya Bhat et al., (32.1\%), Kalyanarooj et al., (35\%) Deora et al., (40.97\%), Tathe et al., (39.14\%) (Ukey et al., (2010), Sandhya Bhat et al., (2014), Kalyanarooj et al., (1997), Deora et al., (2015) and Tathe et al., (2013). Increase in positivity in the present study may partially be attributed to the rapid unplanned urbanization with unchecked construction activities and poor sanitation facilities contributing to fertile breeding grounds for mosquitoes. It is also true that alertness among medical fraternity and availability of diagnostic tests in hospitals have contributed to the increased detection of cases (Mehta et al., 2014).

\section{Clinical features in dengue infection}

The most frequent symptoms observed in dengue positive cases in present study were fever $(100 \%)$ and headache $(77.53 \%)$.

Other symptoms observed in the present study by decreasing order were bodyache $(66.67 \%)$, nausea and vomiting (47.82), joint pain $(45.65 \%)$, abdominal pain $(38.4 \%)$, retroorbital pain $(38.4 \%)$, rash $(21.73 \%)$.

Similar findings were observed by following previous studies shown in Table 12. In the present study hepatomegaly was the commonest sign observed in 21(15.21\%) cases. Ascites was noted in $16(11.59 \%)$ cases followed by pleural effusion in $14(10.14 \%)$ and splenomegaly in $11(7.97 \%)$ cases respectively.

Similar findings observed by Deora et al., (2015), Singh et al., (2005), Bhaskar et al., (2010) Kumar et al., (2015), Shah et al., (2006).

Mortality in our study was $2.89 \%$ which was similar to Kumar et al., (2010), Singh et al., (2005) and Duthade et al., (2013) who found mortality in $2.4 \%, 2.7 \%$ and $3.7 \%$, cases respectively. 


\section{Classification of dengue}

In our study out of 138 dengue positive cases, large proportion of cases i.e. 84 (60.87\%) belonged to the category of dengue without warning signs, followed by 39 cases $(28.26 \%)$ dengue with warning signs and 15 cases $(10.87 \%)$ had severe dengue as shown in Table 11. The present study results were comparable with Deora et al., (2015) who observed 51.69\% dengue without warning signs, $34.75 \%$ dengue with warning signs and $13.55 \%$ severe dengue.

While Jain et al., (2013) observed 76\% dengue without warning signs, $20 \%$ dengue with warning signs and $3 \%$ severe dengue.

Table.1 Seropositivity of dengue virus infection

\begin{tabular}{|c|c|c|}
\hline Total No. of clinically & \multicolumn{2}{|c|}{ Dengue positive } \\
\cline { 2 - 3 } suspected dengue cases & No. of cases & Percentage \\
\hline 390 & 138 & $35.38 \%$ \\
\hline
\end{tabular}

Table.2 Serologically positive cases in Group A, Group B and Total positive cases

\begin{tabular}{|c|c|c|}
\hline $\begin{array}{c}\text { Group A } \\
\text { Positive }\end{array}$ & $\begin{array}{c}\text { Group B } \\
\text { Positive } \\
\text { (RICT \&/or NS1 }\end{array}$ & Total Positive Cases \\
ELISA) & (RICT \&/or IgM & \\
ELISA) & (Total No. of clinically \\
(180 Clinically & (210 Clinically & Suspected Samples \\
Suspected Samples) & Suspected Samples) & $\mathbf{3 9 0})$ \\
\hline 55 & 83 & $138(35.38 \%)$ \\
\hline
\end{tabular}

Table.3 Showing various clinical signs in dengue positive cases

\begin{tabular}{|c|c|c|}
\hline Signs & $\begin{array}{c}\text { Dengue positive } \\
\text { cases }(\mathbf{n}=138)\end{array}$ & Percentage \\
\hline Hepatomegaly & 21 & $15.21 \%$ \\
\hline Ascites & 16 & $11.59 \%$ \\
\hline Pleural effusion & 14 & $10.14 \%$ \\
\hline Splenomegaly & 11 & $7.97 \%$ \\
\hline
\end{tabular}

Table.4 Distribution of serologically positive dengue cases into three categories as per WHO guidelines 2009( 12)

$(n=138)$

\begin{tabular}{|c|c|c|}
\hline Categories of Dengue & Total no. of cases & Percentage \\
\hline Dengue without warning signs & 84 & $60.87 \%$ \\
\hline Dengue with warning signs & 39 & $28.26 \%$ \\
\hline Severe dengue & 15 & $10.87 \%$ \\
\hline Total & $\mathbf{1 3 8}$ & $\mathbf{1 0 0 \%}$ \\
\hline
\end{tabular}


Table.5 Serologically dengue positive cases diagnosed by RICT

$(\mathrm{n}=111)$

\begin{tabular}{|c|c|c|}
\hline Parameter & $\begin{array}{c}\text { Positive } \\
\text { Number }\end{array}$ & Percentage \\
\hline NS1 antigen only & 27 & $24.32 \%$ \\
\hline IgM antibody only & 48 & $43.24 \%$ \\
\hline IgG antibody only & 3 & $2.70 \%$ \\
\hline NS1 antigen +IgM antibody & 14 & $12.61 \%$ \\
\hline NS1 antigen +IgG antibody & 6 & $5.40 \%$ \\
\hline IgM antibody + IgG antibody & 10 & $9.00 \%$ \\
\hline NS1 antigen + IgM antibody + IgG antibody & 3 & $2.70 \%$ \\
\hline Total & $\mathbf{1 1 1}$ & $\mathbf{1 0 0 \%}$ \\
\hline
\end{tabular}

Table.6 RICT positivity in primary and secondary dengue infections

$(n=111)$

\begin{tabular}{|c|c|c|}
\hline RICT & $\begin{array}{c}\text { Primary dengue } \\
\text { infection (\%) } \\
\text { Cases }(\%)\end{array}$ & $\begin{array}{c}\text { Secondary dengue } \\
\text { infection (\%) }\end{array}$ \\
\hline Cases (\%) \\
\hline Positive for only NS1 & $27(24.32 \%)$ & - \\
\hline Positive for only IgM & $48(43.24 \%)$ & - \\
\hline Positive for only NS1 +IgM & $14(12.61 \%)$ & $3(2.7 \%)$ \\
\hline Positive for only IgG & - & $6(5.4 \%)$ \\
\hline Positive for only NS1 +IgG & - & $10(9.0 \%)$ \\
\hline Positive for only IgM + IgG & - & $3(2.7 \%)$ \\
\hline Positive for only NS1 + IgM + IgG & - & $\mathbf{2 2}(\mathbf{1 9 . 8 2} \%)$ \\
\hline Total & $\mathbf{8 9}(\mathbf{8 0 . 1 8 \% )}$ & - \\
\hline
\end{tabular}

Table.7 RICT positive test results by day of fever

\begin{tabular}{|c|c|c|c|}
\hline $\begin{array}{c}\text { Day after onset } \\
\text { of fever }\end{array}$ & $\begin{array}{c}\text { Number of sera } \\
\text { tested }\end{array}$ & $\begin{array}{c}\text { Total RICT NS1 } \\
\text { Ag }\end{array}$ & $\begin{array}{c}\text { Total RICT IgM } \\
\text { positive }\end{array}$ \\
\hline 1 & 10 & 3 & 0 \\
\hline 2 & 25 & 5 & 0 \\
\hline 3 & 39 & 12 & 2 \\
\hline 4 & 48 & 15 & 3 \\
\hline 5 & 58 & 7 & 4 \\
\hline 6 & 72 & 4 & 24 \\
\hline 7 & 60 & 2 & 18 \\
\hline 8 & 38 & 2 & 10 \\
\hline 9 & 25 & 0 & 10 \\
\hline 10 & 15 & 0 & 4 \\
\hline Total & $\mathbf{3 9 0}$ & $\mathbf{5 0}$ & $\mathbf{7 5}$ \\
\hline
\end{tabular}


Table.8 RICT Positivity in Group A (1-5 days) and Group B (6-10 days)

\begin{tabular}{|c|c|c|}
\hline Group & RICT NS1 Ag positive & RICT IgM Ab Positive \\
\hline Group A & $42(84 \%)$ & $9(12 \%)$ \\
\hline Group B & $8(16 \%)$ & $66(88 \%)$ \\
\hline Total & $\mathbf{5 0}(\mathbf{1 0 0 \%})$ & $\mathbf{7 5}(\mathbf{1 0 0 \%})$ \\
\hline
\end{tabular}

$\mathrm{p}$ value $<0.0001$ (Statistically significant)

Table.9 Percentage of Positive results by NS1 ELISA and RICT for NS1 Ag (During 1-5 days of Fever) in Group A

\begin{tabular}{|c|c|c|}
\hline Test & $\begin{array}{c}\text { Total NS1 ag } \\
\text { positive }\end{array}$ & Percentage \\
\hline RICT for NS1 Ag & 42 & $23.34 \%$ \\
& & $(42 / 180)$ \\
\hline NS1 ELISA & 55 & $30.55 \%$ \\
& & $(55 / 180)$ \\
\hline
\end{tabular}

Table.10 Percentage of Positive results by IgM Capture ELISA and RICT for IgM Ab (During 6-10 days of fever) in Group B

\begin{tabular}{|c|c|c|}
\hline Test & Total IgM positive & Percentage \\
\hline RICT for IgM Ab & & $31.42 \%$ \\
& 66 & $(66 / 210)$ \\
\hline IgM capture ELISA & 83 & $39.52 \%$ \\
\hline
\end{tabular}

Table.11 Showing NS1 ELISA Positivity for NS1 Ag and IgM Capture ELISA Positivity for $\operatorname{IgM~Ab}$

\begin{tabular}{|c|c|c|}
\hline ELISA & Positive Results & Positivity \\
\hline NS1 ELISA & 55 & $30.55 \%$ \\
& & $(55 / 180)$ \\
\hline IgM Capture ELISA & 83 & $39.52 \%$ \\
& & $(83 / 210)$ \\
\hline
\end{tabular}


Table.12 Showing occurrence of common symptoms in various studies among dengue positive cases

\begin{tabular}{|c|c|c|c|c|c|c|c|c|c|}
\hline Symptoms & $\begin{array}{l}\text { (Chatterjee } \\
\text { et al., 2014) }\end{array}$ & $\begin{array}{l}\text { (Kashinkunti } \\
\text { et al., 2013) }\end{array}$ & $\begin{array}{l}\text { (Sreejith } \\
\text { et al., } \\
\text { 2014) }\end{array}$ & $\begin{array}{c}\text { (Kauser } \\
\text { et al., 2014) }\end{array}$ & $\begin{array}{c}\text { (Dash } \\
\text { et al., 2005) }\end{array}$ & $\begin{array}{c}\text { (Neeraja } \\
\text { et al., 2006) }\end{array}$ & $\begin{array}{l}\text { (Kumar et } \\
\text { al., 2010) }\end{array}$ & $\begin{array}{c}\text { (Deora } \\
\text { et al., 2015) }\end{array}$ & $\begin{array}{c}\text { Present } \\
\text { study }\end{array}$ \\
\hline Fever & $98 \%$ & $100 \%$ & $100 \%$ & $100 \%$ & $100 \%$ & $100 \%$ & $99.1 \%$ & $100 \%$ & $100 \%$ \\
\hline Headache & $90 \%$ & $90 \%$ & $92 \%$ & $75.34 \%$ & $86 \%$ & $74 \%$ & $47.6 \%$ & $67.79 \%$ & $77.53 \%$ \\
\hline Bodyache & $86 \%$ & $81 \%$ & $89 \%$ & $32.87 \%$ & $70 \%$ & $53 \%$ & $64.6 \%$ & $54.23 \%$ & $66.67 \%$ \\
\hline $\begin{array}{l}\text { Nausea/ } \\
\text { vomiting }\end{array}$ & $24 \%$ & $56 \%$ & $79 \%$ & $57.53 \%$ & $55 \%$ & $62 \%$ & $47.6 \%$ & $48.3 \%$ & $47.82 \%$ \\
\hline Joint pain & - & - & $86 \%$ & $13.69 \%$ & $55 \%$ & - & - & $46.61 \%$ & $46.65 \%$ \\
\hline $\begin{array}{l}\text { Abdominal } \\
\text { pain }\end{array}$ & $42 \%$ & $48 \%$ & - & $26.02 \%$ & $37 \%$ & $22 \%$ & $37.6 \%$ & $39.83 \%$ & $38.40 \%$ \\
\hline $\begin{array}{l}\text { Retro- } \\
\text { orbital pain }\end{array}$ & $90 \%$ & - & $44 \%$ & $12.32 \%$ & - & $7 \%$ & - & $38.98 \%$ & $38.40 \%$ \\
\hline Rash & $28 \%$ & $20 \%$ & - & - & $56 \%$ & $41 \%$ & $21.7 \%$ & $23.72 \%$ & $21.73 \%$ \\
\hline $\begin{array}{l}\text { Hemorrhagi } \\
\text { c /Bleeding } \\
\text { manifesta- } \\
\text { tions }\end{array}$ & $23 \%$ & $21 \%$ & $6 \%$ & $9.58 \%$ & - & $7 \%$ & - & $16.94 \%$ & $15.21 \%$ \\
\hline
\end{tabular}

Table.13 Showing only NS1 positive cases diagnosed by RICT in various studies

\begin{tabular}{|c|c|c|c|c|c|c|c|c|}
\hline Names of studies & $\begin{array}{l}\text { (Ghosh } \\
\text { et al., } \\
\text { 2013) }\end{array}$ & $\begin{array}{l}\text { (Tabasum } \\
\text { et al., } \\
\text { 2014) }\end{array}$ & $\begin{array}{c}\text { (Shah et } \\
\text { al., } \\
\text { 2015) }\end{array}$ & $\begin{array}{l}\text { (Tathe } \\
\text { et al., } \\
\text { 2013) }\end{array}$ & $\begin{array}{l}\text { (Deora } \\
\text { et al., } \\
\text { 2015) }\end{array}$ & $\begin{array}{l}\text { (Kulkarni } \\
\text { et al., } \\
\text { 2011) }\end{array}$ & $\begin{array}{l}\text { (Golia } \\
\text { et al., } \\
\text { 2012) }\end{array}$ & $\begin{array}{c}\text { Present } \\
\text { study }\end{array}$ \\
\hline $\begin{array}{c}\text { Only NS1ag Positive cases diagnosed } \\
\text { by RICT }(\%)\end{array}$ & $51.56 \%$ & $43.24 \%$ & $46 \%$ & $36.55 \%$ & $29.09 \%$ & $30 \%$ & $23.3 \%$ & $24.32 \%$ \\
\hline
\end{tabular}


Table.14 NS1 ELISA Positivity for NS1 Ag and IgM ELISA Positivity for IgM Ab in various studies

\begin{tabular}{|c|c|c|c|c|c|c|c|c|c|c|}
\hline Studies & $\begin{array}{c}\text { (Shrivastava et al., } \\
\text { 2011) }\end{array}$ & $\begin{array}{l}\text { (Solanke } \\
\text { et al., } \\
\text { 2015) }\end{array}$ & $\begin{array}{c}\text { (Patil et } \\
\text { al., 2014) }\end{array}$ & $\begin{array}{l}\text { (Ahmed } e t \\
\text { al., 2015) }\end{array}$ & $\begin{array}{l}\text { (Sahu et } \\
\text { al., 2015) }\end{array}$ & $\begin{array}{l}\text { (Manohar et } \\
\text { al., 2015) }\end{array}$ & $\begin{array}{l}\text { (Datta et } \\
\text { al., 2010) }\end{array}$ & $\begin{array}{l}\text { (Kassim et } \\
\text { al., 2011) }\end{array}$ & $\begin{array}{c}\text { (Solanke } \\
\text { et al., } \\
\text { 2013) } \\
\end{array}$ & $\begin{array}{l}\text { Present } \\
\text { study }\end{array}$ \\
\hline $\begin{array}{l}\text { NS1 ELISA } \\
\text { positivity }\end{array}$ & $26 \%$ & $30.3 \%$ & - & _ & $36.02 \%$ & $29.2 \%$ & $23.3 \%$ & $32.2 \%$ & $28.4 \%$ & $30.55 \%$ \\
\hline $\begin{array}{l}\text { IgM ELISA } \\
\text { positivity }\end{array}$ & _ & - & $35.58 \%$ & $38.9 \%$ & $18.02 \%$ & $48.9 \%$ & $39.1 \%$ & $40.9 \%$ & $40.9 \%$ & $39.52 \%$ \\
\hline
\end{tabular}

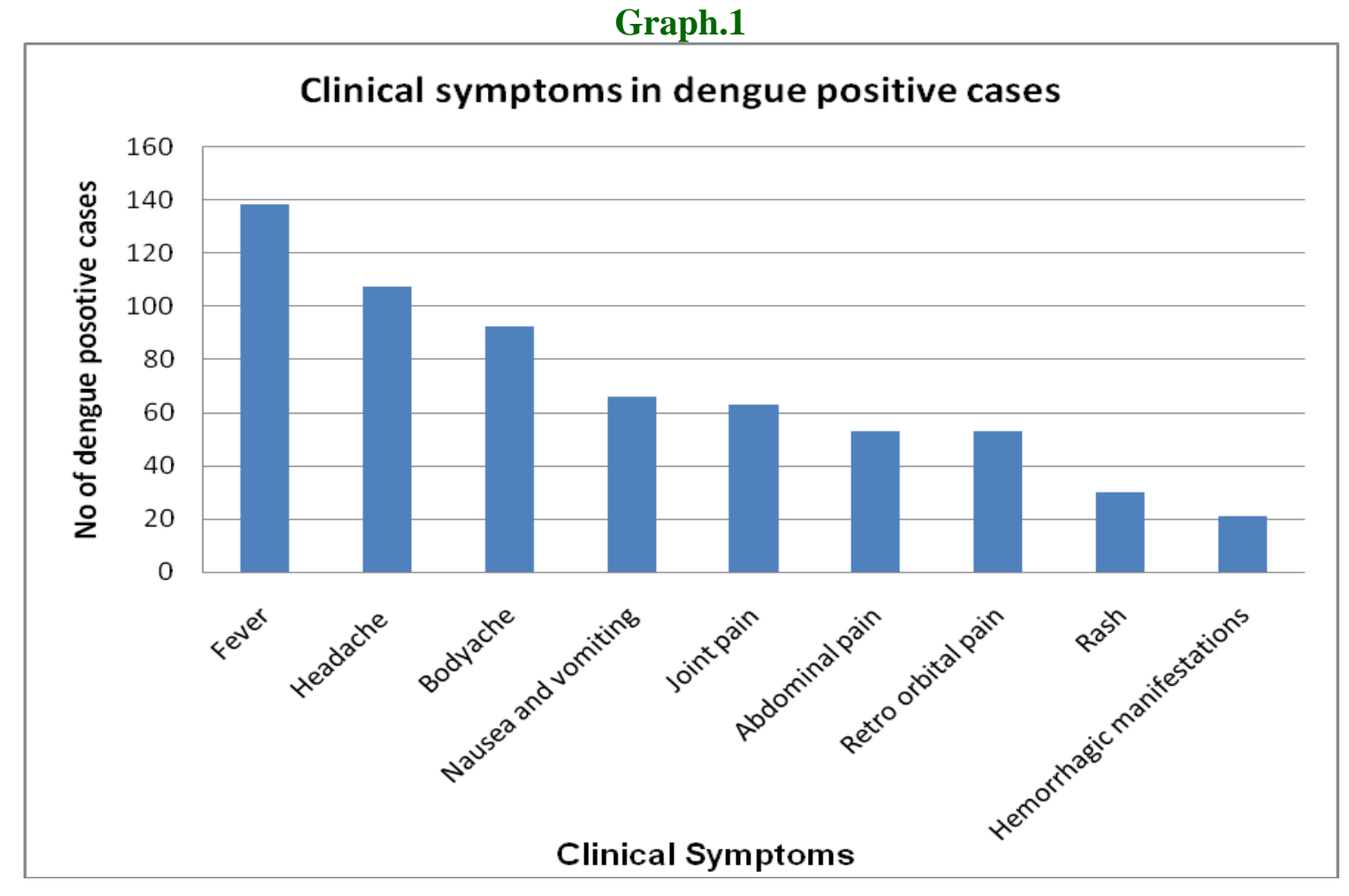




\section{RICT results}

Table 13 shows serologically positive cases diagnosed by RICT. Out of 111 cases positive by RICT, 27 cases $(24.32 \%)$ were positive for NS1 antigen only.

Results of the present study were consistent with following studies shown in Table 13. NS1 Ag was also positive in combination with $\operatorname{IgM} \mathrm{Ab}(12.61 \%)$, IgG $\mathrm{Ab}$ (5.4\%) and $\operatorname{IgM}+\operatorname{IgG~} \mathrm{Ab}(2.7 \%)$ by RICT as shown in Table 13. Thus in the present study NS1 antigen in combination with $\operatorname{IgM~Ab}, \operatorname{IgG~Ab}$ and $\operatorname{IgM~Ab}+\operatorname{IgG} \mathrm{Ab}$ was positive in $20.71 \%$ of the cases.

Similar results observed by Shah et al., (2015) who found NS1 antigen in combination with

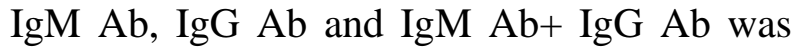
positive in $16 \%$ of the cases. In the present study $\mathrm{IgM} \mathrm{Ab}$ positivity by RICT was $43.24 \%$.

Results of the present study were consistent with that of Deora et al., (2015), Kulkarni et al., (2011) and Golia et al., (2012) who found only IgM positivity by RICT in $43.63 \%, 50 \%$ and $33.3 \%$ of the cases respectively.

IgM Ab was also positive in combination with NS1 antigen (12.61\%), IgG Ab (9.0\%) and $\mathrm{NS} 1+\operatorname{IgG~} \mathrm{Ab}(2.7 \%)$ by RICT as shown in Table 13.

Thus in the present study $\operatorname{IgM} \mathrm{Ab}$ in combination with NS1 antigen, IgG Ab and NS1 Antigen+IgG Ab was positive in $24.31 \%$ of the cases.

Similar results observed by Shah KD et al., who found IgM Ab in combination with NS1 antigen, $\mathrm{IgG} \mathrm{Ab}$ and NS1 Antigen $+\mathrm{IgG} \mathrm{Ab}$ was positive in $26 \%$ of the cases (Shah et al., 2015).

\section{Primary and secondary infection}

In the present study, $89(80.18 \%)$ primary dengue infection and $22(19.82 \%)$ secondary dengue infection cases were detected.

Similar findings were observed by Jayasimha et al., (2012) who also found $82.6 \%$ primary dengue infection and (17.3\%) secondary dengue infection cases.

Shah et al., (2015) and Saini et al., (2013) found $85 \%, 84.6 \%$ primary dengue infection and $15 \%, 15.3 \%$ secondary dengue infection cases respectively.

\section{RICT NS1 Ag and IgM Ab positivity according to days of fever}

Table 9 shows NS1 antigen was detectable in patient's sera from day one of fever, IgM antibodies from day 3 onwards and NS1 Ag was detected in patients sera till the $8^{\text {th }}$ day of fever by RICT.

The present study findings were in tune with that of Deora et al., (2015) and Chakravarti et al., (2011) who detected NS1 Ag from day one of fever, IgM antibody from day three of symptoms and NS1 Ag detected upto the $8^{\text {th }}$ and $7^{\text {th }}$ day of fever respectively. Shah et al., (2015) who detected NS1 Ag till $7^{\text {th }}$ day of fever while Alcon et al., (2002) and Kassim et al., (2011) found NS1 Ag in patients sera till day $9^{\text {th }}$ of fever. In our study NS1 Ag was positive for about 50 number of patients with a maximum positivity on $4^{\text {th }}$ day $(30 \%)$ followed by on $3^{\text {rd }}$ day $(24 \%)$. Similar findings observed by Patel et al., (2013) who found maximum NS1 Ag positivity on day 4th day (61\%) followed by 3rd day $16.7 \%$. While Chithambaram et al., (2014) found maximum NS1 Ag positivity on day 4-5 (61.2\%) and Deora et al., (2015) found maximum NS1 Ag positivity on $5^{\text {th }}$ day (24.44) followed by $6^{\text {th }}$ (20\%), $4^{\text {th }}$ day $(13.34 \%)$. 
IgM was positive for about 75 number of patients with a maximum positivity on $6^{\text {th }}$ day $(32 \%)$ and $7^{\text {th }}$ day $(24 \%)$. Similar findings observed by Deora et al., (2015) and Kassim et al., (2011) who found maximum IgM positivity on $5^{\text {th }}$ and $6^{\text {th }}$ day. While Shah KD et al., found maximum $\operatorname{IgM}$ positivity on $5^{\text {th }}$ day (Shah et al., 2015)

\section{RICT NS1 Ag and IgM positivity in group $A$ and group $B$}

In our study RICT NS1 ag positivity was $84 \%$ in Group A (1-5 days) and 16\% in Group B (6-10 days) (Table 10). The NS1 Ag detection rate decreased from $84 \%$ in $1-5$ days sera to $16 \%$ in 6-10 days sera. Similar results observed by Datta et al., (2010) who found $71.42 \%$ NS1 Ag positive were from acute phase serum samples and $28.4 \%$ were from early convalescent phase. Shah et al., (2015) found NS1 ag was positive in $17.7 \%$ cases between 1-3 days, $61.2 \%$ cases between day 4-5, 20.9\% cases positive between 6 - 7days.

Solanke et al., (2015) found the NS1 Ag positivity also decreased from $47.3 \%$ on days $1-3$ to $39.4 \%$ on days 4-6 and further decreased to $13.1 \%$ on days 7-9. Solanke et al., (2013) found NS1 Ag positive in $70.73 \%$ cases on day $1 \& 2$ and decreased upto $4.87 \%$ on day 5.

In our study RICT IgM positivity was $12 \%$ in Group A (1-5 days) and 88\% in Group B (610 days) (Table 10). The IgM Ab detection rate increased from $12 \%$ in $1-5$ days sera to $88 \%$ in 6-10 days sera.

Similar results observed by Datta et al., (2010) who found $93.61 \%$ IgM positive samples were from early convalescent phase and only $6.38 \%$ were positive from acute phase sera.

Solanke et al., (2013) found IgM positive in $5.06 \%$ cases from day 5 onwards and gradually increased up till day 9 in $50.54 \%$ of cases.

\section{NS1 ELISA positivity for NS1 Ag and IgM ELISA Positivity for IgM Ab}

In the present study 55 Samples were positive by NS1 ELISA and NS1 ELISA positivity for NS1 Ag (For Group A) was $30.55 \%$ where as 83 samples were positive by IgM Capture ELISA and IgM ELISA positivity for IgM Ab was $39.52 \%$ which was similar to following studies shown in Table 14.

NS1 protein was found to be highly conserved for all dengue serotypes, circulating in high levels during the first few days of illness. The dengue NS1 antigen was not found in patients with Japanese encephalitis virus or yellow fever virus infections thereby implying that there is no cross-reaction of dengue NS1 protein with those of other related flaviviruses. Thus detection of NS1 has been a promising test to diagnose dengue in its early febrile stage (Shrivastava et al., 2011).

Results of higher percentage of $\operatorname{IgM}$ positivity in the present study was because most of the patients visit health care facility at later (more than 5 days) stage of illness when antibody detection remains the choice of test (Patil, 2014).

RICT provide the useful aids in screening and ELISA should be considered as the confirmatory test in diagnosis of dengue.

NS1 ELISA has promising results in early diagnosis of dengue and when used in combination with IgM Capture ELISA it increases the diagnostic efficiency.

Early diagnosis of dengue helps to reduce the indiscriminate use of antimalarials and antimicrobials for treatment of patients with febrile illness. 
Hence involvement of good laboratories for early and prompt diagnosis of dengue infection, coupled with vector control programmes and inducing awareness among the public, is needed in combating future epidemics of dengue.

\section{References}

Ahmed NH, Broor S. Comparison of NS1 antigen detection ELISA, real time RT-PCR and virus isolation for rapid diagnosis of dengue infection in acute phase. J Vector Borne Dis. 2014 Sept; 51(3): 194-9.

Ahmed NH, Broor S. Dengue Fever Outbreak in Delhi, North India: A ClinicoEpidemiological Study. Indian J Community Med.2015 April; 40(2): 135-8.

Alcon S, Talarmin A, Debruyne M, Falconar A, Deubel V, Flamand M. Enzymelinked immunosorbent assay specific to Dengue virus type 1 nonstructural protein NS1 reveals circulation of the antigen in the blood during the acute phase of disease in patients experiencing primary or secondary infections. J Clin Microbiol. 2002 Feb; 40(2): 376-81.

Bhaskar ME, Moorthy S, Kumar NS, Arthur P. Dengue Haemorrhagic Fever among Adults - An Observational Study in Chennai, South India. Indian J Med Res. 2010 Dec; 132: 738-40.

Chakravarti A, Kumar A, Malik S. Detection of dengue infection by combining the use of an NS1 antigen based assay with antibody detection. Southeast Asian J Trop Med Public Health. 2011Mar; 42 (2): 297-302.

Chatterjee N, Mukhopadhyay M, Ghosh S, Mondol M, Das C, Patar K. An observational study of dengue fever in a tertiary care hospital of Eastern
India. J Assoc Physicians India. 2014 March; 62: 224-7.

Chithambaram N S, Shah KD. To Evaluate the Role of NS1 Antigen for Early Detection of Dengue Fever. J Evol Med Dent Sci. 2014 Dec; 3(71): 14463-9.

Dash PK, Saxena P, Abhyankar A, Bhargava R, Jana AM. Emergence of dengue virus type-3 in northern India. Southeast Asian J Trop Med Public Heal. 2005 March; 36(2): 370-7.

Datta S, Wattal C. Dengue NS1 antigen detection: a useful tool in early diagnosis of dengue virus infection. Indian J Med Microbiol. 2010 AprJun; 28(2): 107-10.

Deora(Kaswa) P, Bhalchandra M, Mulay V. Early diagnosis of Dengue- Need of the hour. National Journal of Medical Sciences. 2015 Jan; 4(1):60-65.

Dussart P, Labeau B, Lagathu G, Louis P, Nunes MRT, Rodrigues SG, et al., Evaluation of an Enzyme Immunoassay for Detection of Dengue Virus NS1 Antigen in Human Serum. Clin Vaccine Immunol. 2006 Nov; 13(11): 1185-9.

Duthade MM, Bhakare JB, Damle AS. Clinical profile of dengue haemorrhagic fever from Jan 2009 to Dec 2009 in and around Aurangabad. J Eval Med Dent Sci. 2013 Dec; 2(48): 9426-9.

Ghosh G, Urhekar AD, Kosta S. A ClinicoMicrobiological study of dengue fever in a tertiary care centre of Navi Mumbai. Int J Bioassays. 2013; 2(11): 1462-7.

Golia S, Hittinahalli V, Karjigi KS, Reddy M, Kamath AS. Serodiagnosis of dengue using NS1 antigen, dengue IgM, dengue $\operatorname{IgG}$ antibody with correlation of platelet counts. International Journal of A J Institute of Medical Sciences 2012 Nov; 1(2): 112-7. 
Gupta E, Ballani N. Current perspectives on the spread of dengue in India. Infect Drug Resist. 2014 Dec 11; 7: 337-42.

Jain A, Shah AN, Patel P, Desai M, Somani S, Parikh $\mathrm{P}$, et al., A clinicohematological profile of dengue outbreak among healthcare professionals in a tertiary care hospital of Ahmedabad with analysis on economic impact. Natl J Community Med. 2013 Apr-Jun; 4(2): 286-90.

Jayasimha VL, Thippeswamy MTR, Yogesh Babu KV, Vinodkumar CS, Niranjan HP. Raghukumar K.G, et al., Dengue: Seroprevalence, Comparison of Rapid Test With Elisa. National Journal of Basic Medical Sciences 2012 Jul-Sept; 3(1): 57-60.

Kalayanarooj S, Vaughn DW, Nimmannitya S, Green S, Suntayakorn S, Kunentrasai $\mathrm{N}$, et al., Early clinical and laboratory indicators of acute dengue illness. J Infect Dis. 1997 Aug; 176(2): 313-21.

Kashinkunti MD, Shiddappa, Dhananjaya M. A study of clinical profile of dengue fever in a tertiary care teaching hospital. Sch J Appl Med Sci. 2013; 1(4): 280-2.

Kassim FM, Izati MN, TgRogayah T, Apandi YM, Saat Z. Use of dengue NS1 antigen for early diagnosis of dengue virus infection. Southeast Asian J Trop Med Public Health. 2011 May; 42(3): 562-9.

Kauser MM, Kalavathi GP, Radadiya M, Karthik M, Afreen A, Kumaraswamy RC. et al., A Study of Clinical and Laboratory Profile of Dengue Fever in Tertiary Care Hospital in Central Karnataka, India. Glob J Med Res. 2014; 14(5): 7-12.

Kulkarni RD, Patil SS, Ajantha GS, Upadhya AK, Kalabhavi AS, Shetty PC, et al., Association of platelet count and serological markers of dengue infection importance of NS1 antigen. Indian J Med Microbiol. 2011 Jan; 29(4): 359-62

Kumar A, Rao CR, Pandit V, Shetty S, Bammigatti C, Samarasinghe CM. Clinical manifestations and trend of dengue cases admitted in a tertiary care hospital, Udupi district, Karnataka. Indian J Community Med. 2010 Jul; 35(3): 386-90.

Kumar MP, Kulkarni S, Rohit A, Bhandarkar AP. Dengue -A clinicoepidemiological study in a tertiary care hospital of north Karnataka, India. International Journal of Current Research. 2015 May; 7(5), 16123-6.

K SB, Sastry AS, Senthamarai S, Sivasankari S. Seroprevalence of dengue viral infection in patients attending to a tertiary care hospital in Kanchipuram, Tamil Nadu, India. Int J Res Health Sci. 2014 Jul 31; 2(3): 818-22. Available from http://www.ijrhs.com/issues.php? val $=$ Volume $2 \&$ iss $=$ Issue 3 accessed on 12 October 2015.

Mahapatra D, Sarangi G, Mahapatra A, Paty BP, Das P, Chayani N. NS1 Antigen Capture ELISA an Effective Method for Diagnosis of Early Dengue Infection-Report of an Outbreak at Angul District, Odisha, India. J Clin Diagn Res. 2014Aug; 8(8): 8-10.

Manohar B, Kumar BS, Prasanna L, Dudala SR, Kumar CN, Sailaja A. Clinical and microbiological profile of Acute Dengue infection in teaching hospital. Indian Journal of Basic and Applied Medical Research. 2015 Mar;4(2):4018.

Mehta KD, Gelotar PS, Vachhani SC, Makwana N, Sinha M. Profile of dengue infection in Jamnagar city and district, west India. WHO South-East Asia J Public Health.2014 Jan-Mar; 3(1): 72-4. 
Moorthy M, Chandy S, Selvaraj K, Abraham AM. Evaluation of a rapid immunochromatographic device for the detection of IgM \&amp; IgG antibodies to dengue viruses (DENV) in a tertiary care hospital in south India. Indian J Med Microbiol. 2009; 27(3): 254-6.

Neeraja M, Lakshmi V, Teja VD, Umabala P Subbalakshmi MV. Serodiagnosis of dengue virus infection in patients presenting to a tertiary care hospital. Indian J Med Microbiol. 2006; 24(4): 280-2.

Patel LR. Sero prevalence of Dengue NS-1 Antigen in Tertiary care hospital, Ahmedabad. Indian J Basic Appl Med Res. 2013 Jun; 7(2): 694-701.

Patil AA, Baveja SM, Mehta PR. Laboratory Diagnosis of Dengue: Utility of Combination of Diagnostic Tests at Tertiary Care Hospital. International Journal of Recent Trends in Science And Technology. 2014; 11(1): 119-21.

Sahu SK, Ghosh SK, Behera SK, Mohanty DP, Thakur S. Use of a rapid test kit and ELISA for detection of NS1 antigen and $\operatorname{IgM}$ antibody in suspected dengue fever. International Journal of Microbiology and Parasitology 2015; 1(1): 1-3.

Saini S, Kinikar AG, Deorukhkar S, Bhalerao D, Roushani SB. Epidemiology and seropositivity of dengue fever cases in a rural tertiary care hospital of western Maharashtra, India. Int $\mathbf{J}$ Biomed Adv Res. 2013; 4(7): 473-7.

Shah GS, Islam S, Das BK. Clinical and laboratory profile of dengue infection in children. Kathmandu Univ Med J. 2006; 4(1): 40-3.

Shah KD, Chithambaram NS, Katwe N. Effectiveness of serological tests for early detection of dengue fever. Sch $\mathbf{J}$ Appl Med Sci. 2015; 3(1D): 291-6.
Shrivastava A, Dash PK, Tripathi NK, Sahni AK, Gopalan N, Lakshmana Rao PV. Evaluation of a commercial dengue NS1 enzyme-linked immunosorbent assay for early diagnosis of dengue infection. Indian $\mathrm{J}$ Med Microbiol. 2011; 29(1): 51-5.

Singh NP, Jhamb R, Agarwal SK, Gaiha M, Dewan R, Daga MK, et al., The 2003 outbreak of Dengue fever in Delhi, India. Southeast Asian J Trop Med Public Heal. 2005Sept; 36(5): 1174-8.

Solanke VN, Karmarkar MG, Mehta PR. Early dengue diagnosis: Role of rapid NS1 antigen, NS1 early ELISA, and PCR assay. Trop J Med Res. 2015 JulDec;18(2):95-9.

Solanke VN, Mody MB, Karmarkar MG, Mehta PR. Utility of battery of tests for accurate serodiagnosis of dengue. Int $\mathbf{J}$ Biol Med Res. 2013; 4(4): 3629-32.

Sreejith MG, George P. Study on the diagnostic efficacy of clinicolaboratory parameters in serologically diagnosed cases of dengue fever. International Journal of Recent Trends in Sciences And Technology. 2014; 11(1): 12-6.

Stephen S, Charles MV, Anitharaj V, Deepa $\mathrm{C}$, Umadevi S. Early dengue diagnosis by nonstructural protein 1 antigen detection: Rapid immune chromatography versus two the enzyme-linked immunosorbent assay kits. Indian J Pathol Microbiol. 2014 Jan-Mar; 57(1): 81-4.

Tabasum BM, Sumana MN, Basavana GH. Evaluation of Rapid ICT in comparison with MAC-ELISA in diagnosis of dengue fever at a tertiary care hospital, South India. International Journal of Pharmaceutical Science Invention. 2014 Dec; 3(12): 11-6.

Tathe SS, Chincholkar VV, Kulkarni DM, Nilekar SL, Oval RS, Halgarkar CS. A 
study of NS1 antigen and platelet count for early diagnosis of dengue infection. Int J Curr Microbiol Appl Sci. 2013; 2(12): 40-4.

Ukey PM, Bondade SA, Paunipagar PV, Powar RM, Akulwar SL. Study of seroprevalence of dengue Fever in central India. Indian J Community Med. 2010 Oct; 35(4): 517-9.

Vaughn DW, Nisalak A, Kalayanarooj S, World Solomon T, Dung NM, Cuzzubbo A, et al., Evaluation of a rapid immunochromatographic test for diagnosis of dengue virus infection. $\mathbf{J}$
Clin Microbiol. 1998 Jan; 36(1): 2348.

Wang SM, Sekaran SD. Evaluation of a commercial SD dengue virus NS1 antigen capture enzyme-linked immunosorbent assay kit for early diagnosis of dengue virus infection. $\mathbf{J}$ Clin Microbiol. 2010Aug; 48(8): $2793-$ 7.

Health Organization. Dengue: Guidelines for diagnosis, treatment, prevention and control. New edition. Geneva: World Health Organization; 2009.

\section{How to cite this article:}

Arjun Gajananrao Jadhav, Anil Arjunrao Gaikwad and Ajit S. Damale. 2019. ClinicoMicrobiological Study of Dengue Virus Infection in A Tertiary Care Hospital. Int.J.Curr.Microbiol.App.Sci. 8(12): 1646-1662. doi: https://doi.org/10.20546/ijcmas.2019.812.198 